\title{
Evaluation of the Habitual Amaranth (Amaranthus Spp) Consumption Effect on Biochemical and Anthropometric Indicators of a Women's Group with Diabetes Mellitus 2 in Michoacán, México
}

\begin{abstract}
María Antonieta Ochoa Ocaña ${ }^{1 *}$, Olivia González Mendoza ${ }^{2}$, Andrés Del Ángel Escalona ${ }^{3}$, Eduardo Alejandro López Sánchez ${ }^{4}$, Celia Salceda Contreras ${ }^{5}$, Enrique Vázquez Rosas ${ }^{6}$, Fernando Alanisz Ibarra ${ }^{7}$, Sandra María Flores Anaya ${ }^{8}$, Karina Guadalupe Silva Ledesma ${ }^{9}$ and Fátima Yanelli Chairez Aguilera ${ }^{10}$

${ }^{1}$ Unidad Académica de Estudios Regionales de la Coordinación de Humanidades, UNAM. Lázaro Cárdenas esq. Felicitas del Río s/n CP 59510 Jiquilpan de Juárez, Michoacán, México

${ }^{2}$ Universidad Instituto Gastronómico de Estudios Superiores, Hacienda Buenavista 206. Jardines de la Hacienda CP 76180 Querétaro, Querétaro, México

${ }^{3}$ Instituto de Investigaciones Antropológicas, UNAM, Ciudad Universitaria. Coyoacán CP 04510 Ciudad de, México

${ }^{4}$ Unidad Académica de Estudios Regionales de la Coordinación de Humanidades, UNAM Lázaro Cárdenas esq Felicitas del Río s/n Jiquilpan de Juárez, Michoacán, México
\end{abstract}

${ }^{5}$ Universidad del Valle de Atemajac Plantel Zamora Jacona (UNIVA), Jefatura del Departamento de Ciencias de la Salud. Madero Sur 310 Centro CP 59600 Zamora, Michoacán, Mexico

${ }^{6}$ Centro de Salud Cojumatlán Secretaría de Salud, Justo Sierra No 25 CP 59140 Cojumatlán de Régules, Michoacán, Mexico

${ }^{7}$ Private Consultant in Gastronomy Juan de la Barrera No 21 C P 59160 Venustiano Carranza, Michoacán, Mexico

${ }^{8}$ Private Consultant in Nutrition, Franco Rodríguez 201 CP 59030 Sahuayo, Michoacán, México

${ }^{9}$ Private Consultant in Nutrition, Miguel Alemán 558 CP 59560 Zamora, Michoacán, México

${ }^{10}$ Private Consultant in Nutrition, Madero Sur 310 Centro, CP 59600 Zamora, Michoacán, México

*Corresponding author: María Antonieta Ochoa Ocaña, Unidad Académica de Estudios Regionales de la Coordinación de Humanidades, UNAM. Lázaro Cárdenas esq. Felicitas del Río s/n CP 59510 Jiquilpan de Juárez, Michoacán, México

\section{ARTICLE INFO}

Received: 輩 October 15, 2021

Published: 慧 October 26, 2021

Citation: María Antonieta Ochoa Ocaña, Olivia González Mendoza, Andrés Del Ángel Escalona, Eduardo Alejandro López Sánchez, Celia Salceda Contreras, et al., Evaluation of the Habitual Amaranth (Amaranthus Spp) Consumption Effect on Biochemical and Anthropometric Indicators of a Women's Group with Diabetes Mellitus 2 in Michoacán, México. Biomed J Sci \& Tech Res 39(4)-2021. BJSTR. MS.ID.006330.

\begin{abstract}
Diabetes Mellitus 2 is a multifactorial disease whose global and national dimensions require a multidisciplinary approach for its control, with nutrition being a fundamental part of this within a healthy lifestyle. The study's objective was to evaluate the effect of amaranth as a functional food in a group of women with Diabetes Mellitus 2 (DM2) in Michoacán, Mexico over a year, previously with their informed consent. It was of a longitudinal, prospective, and intervention type. Among the comparative results of the beginning and end of the study, it is worth noting that the average blood glucose level decreased 29.86mg / d (118.9 / 89.04); there was an increase in high- density lipoprotein; moreover, the patients did not increase their body weight. The results suggest that amaranth as a food of habitual consumption represents an alternative of health and nutrition for the patient with DM2.
\end{abstract}

Keywords: Health; Glycemic Level; Prevalence; Prevention

Abbreviations: DM: Diabetes Mellitus; FAO: Food and Agriculture Organization of the United Nations; WHO: World Health Organization; UNU: United Nations University; ACE: Angiotensin-Converting Enzyme; DPP IV: Dipeptidyl Peptidase IV Enzyme; BMI: Body Mass Index 


\section{Introduction}

Diabetes mellitus 2 is a metabolic, chronic, and systemic disease of multifactorial origin, caused by an alteration in insulin production, use, or action. The diabetes risk factors cover advanced age, ethnic minorities, generalized obesity, adiposity, and socioeconomic status [1]. Type 2 Diabetes mellitus (DM2) occurs at any age, generally over 40 years of age, increasing its risk through obesity, lack of physical activity, dyslipidemias, family history of gestational diabetes, hypertension, and age. In most cases, modifying the lifestyle can avoid the disease. The predominance of diabetes is higher in developed countries. However, its proportional increase is higher in developing countries [2]. DM2 is a chronic disease of great epidemiological interest due to its strong relationship with society's progress. The disease prevalence and incidence have been rising parallel with obesity, sedentary lifestyle, and age [3]. Its primary manifestation is chronic hyperglycemia, which affects the intermediate metabolism of carbohydrates, proteins, and fats [4]. Diabetes is one of the world's leading health problems, and it is considerably affected by excessive body weight and physical inactivity [5]. This pathology has positioned itself in recent decades as a fundamental cause of premature morbidity and mortality worldwide [4]. It is essential to notice that the pathology mentioned above without adequate control leads to a series of micro and macrovascular comorbidities that significantly affect the patient's quality of life and life expectancy. On the other hand, specialists diagnose more frequently DM2 and, in most cases, under advanced stages of late complications [6].

It is worth noting that a component of the treatment of this pathology involves lifestyle modifications, including diet and physical activity, and medication, considering diet modification as the fundamental pillar of its treatment [7]. Several studies have shown that interventions based on diet and exercise reduce the risk of developing DM, are helpful for its treatment, and support the delay of its complications by reducing the abdominal circumference, improving insulin sensitivity, decreasing the plasma glucose and triglyceride concentrations, as well as increased HDL8 values [8]. Over more than three decades, DM2 has gradually formed a lousy panorama in Mexico's public health, frequently associated with obesity and a sedentary lifestyle. The Ministry of Health considers diabetes as the most significant health challenge. This statement represents a clear example of the epidemiological and health care transition that the country is experiencing nowadays. Our country ranks worldwide sixth with people with diabetes [9] (IFD, 2013). During the past few decades, the number of people who have diabetes in Mexico has increased, and it is currently among the leading causes of death in the country [9]. The data identify 6.4 million Mexican adults with diabetes, signifying 9.2\% of adults in Mexico have already received a diabetes diagnosis [10]. The national strategy for preventing and controlling diabetes mellitus is creating indicators to improve eating habits and exercise. However, mortality has increased by $17 \%$ since its implementation [11]. In Mexico, the average age of people who died from diabetes in 2010 was 66.7 years, suggesting a reduction of 10 years of life expectancy; thus, the seriousness of the diabetes epidemic and the fact that it is a preventable disease call for strengthening strategies to deal with it. Its impact on the quality of life of people who suffer from it makes this disease a priority for the health sector [12].

In Michoacán, according to the Ministry of Health's data [13], the problems faced by the State in terms of health are characterized by uncontrolled growth of chronic-degenerative diseases. Such as hypertension, obesity, and DM2, for the last one, up to December 2012, was reported 17603 diabetics under treatment in the first level care units. Concerning amaranth, its cultivation antecedents are ancient. Due to its origin and use, it can be considered a native crop of Mesoamerica. Its cultivation dates to approximately 5000 years BC; amaranth or huauhtli was a cereal with high social, religious, and economic importance before the Conquest. Back then, it was as valuable as the cultivation of corn and beans. Amaranth has a high agri-food potential since its seed, plant, and leaves have nutritional values that surpass some commonly used cereals [14]. The analyzes indicate that the contents of crude proteins, lipids, fiber, and ashes of amaranth, in general, are higher than those of grains, while the proportion of carbohydrates is lower. Amaranth seeds contain around 13 to $18 \%$ crude protein, although some authors have found 15 to $22 \%$ values. Amaranth proteins are mainly found in the embryo (65\%), unlike corn, rice, or soybeans, with $80 \%$ of their proteins in the endosperm [15]. Amaranth proteins meet the requirements of essential amino acids, according to the standards for adults established in 1985 in the joint report of the Food and Agriculture Organization of the United Nations (FAO), the World Health Organization (WHO), and the United Nations University (UNU). Several studies have focused on evaluating and studying the ability of amaranth to complement the protein quality of other grains, such as corn, wheat, and beans. In combination with roasted amaranth flour, corn constitutes a source of protein that can satisfy the requirements of children and teenagers.

Amaranth, known as kiwicha in some Central and South American countries, has already achieved a renowned and marked interest along with other grains considered "super grains," such as quinoa, chia, millet, and sorghum, these as an alternative in combating food security and rural development problems [14]. From the perspective of its potential as a functional food, amaranth contains several potentially essential agents in reducing blood cholesterol, such as dietary fiber, squalene, tocotrienols -which are forms of vitamin E- and isoprenoids [16]. Dietary fiber contains indigestible polysaccharides, oligosaccharides, lignin, and substances associated with the plant. The calcium, magnesium 
boron, iron, and aluminum content are higher than in the seeds of other cereals. Among the most representative bioactive peptides are the Angiotensin-Converting Enzyme (ACE) and Dipeptidyl Peptidase IV Enzyme (DPP IV) inhibitors. DPP IV is responsible for the degradation of insulinotropic hormones related to stimulating the synthesis and promoting insulin secretion by the pancreas' beta cells, thus lowering blood glucose levels [17]. In the last decades, amaranth has been of great importance due to the functional properties of its macromolecules, mainly proteins. A bioinformatic study showed the existence of encrypted sequences in the reserve proteins of the amaranth grain. Through enzymatic hydrolysis, can be released peptides with various biological functions such as inhibitors of Angiotensin-Converting Enzyme I (iECA-I) and DPP-IV, which are - in that order - the activities of the peptides that occur with the highest frequency of appearance in the proteins of this pseudocereal [18].

The use of DPP-IV inhibitors increases the time of action of these hormones and enhances their effects. There are several types of DPPIV inhibitors that have shown promising results as antidiabetic agents. Besides the hypoglycemic effect, people treated with methanolic extract of amaranth or glibenclamide presented similar cholesterol levels, triglycerides, HDL, LDL, VLDL, and serum phospholipids [19]. Studies in rats fed with diets high in cholesterol demonstrate the positive effect of amaranth consumption on plasma lipid profiles [20]. In contrast, the cholesterol-lowering effects in hamsters produced by consuming protein, whole grain, and amaranth oil isolates [21]. To summarize, apart from its high nutritional value, amaranth is a source of bioactive peptides and a series of phytochemical compounds with beneficial properties for human health and with potential biotechnological development [22]. Moreover, the food product's multiple nutritional and health-benefit properties from the culinary perspective have great versatility for agribusiness and culinary preparations at the domestic level.

\section{Methodology}

The research was conducted among 32 women with DM2, with an average age of 68 years, belonging to the Grupo de Diabéticos of Centro de Salud-Secretaría de Salud of Cojumatlán de Régules, Michoacán. The municipality choice was because DM2 is among the three leading causes of morbidity and mortality between 2000 and 2012, according to the Sanitary Jurisdiction Number 2 of Zamora's data. Indicating an epidemiological profile in which this pathology represents a significant public health problem, surpassing these data the rest of the municipalities in the Ciénega de Chapala region. The patients received a breakfast enriched with 30 grams of amaranth in grain and 12 grams of amaranth leaf, from Monday to Friday, calculated this mealtime according to a diet that provided 1800 kilocalories. The study ran from March to November 2015. The patients did not present any complications derived from DM2 nor protein restriction by their treating physician. Furthermore, they did not modify the schedule of their pharmacological treatment or their diet at home. Every four months, the patients obtained an evaluation of their biochemical indicators (glucose, cholesterol, and triglycerides) and body weight and body mass index (BMI). Between the second and third quarters, the patients completed a lipid profile. Moreover, a food and nutritional orientation program supplemented the food intervention. Initially, the patients received a diet of 1800 kilocalories according to the patients' requirements. Since all the patients had some degree of obesity or were overweight, the study restricted to people with not present kidney failure to avoid protein restriction on a patient's diet. Amaranth enriched their diet (popped grain -30g- and leaf -12g-), considering the regional food culture [23], and given the versatility of this food, local preparations used it at a low cost.' The study performed a descriptive statistical analysis from the data of 27 remaining patients. It evaluated the differences through non-parametric techniques: Friedman test, followed by Wilcoxon matched-pairs signed rank test (analogous to the analysis of variance and parametric post hoc tests), given the sample size and the non-corroboration of the assumption of normality of the distribution of the variables of interest. The research followed the established in the Reglamento de la Ley General de Salud en Materia de Investigación para la Salud, and it was approved by the Comisión de Bioética del Estado de Michoacán.

\section{Results and Discussion}

Depicted below are some general results observed during the study. It is important to remark that there was a shortage of amaranth during December, which impacted the biochemical data of the patients (Chart 1). The decrease in glucose levels is observed in the patients, being more significant during the blood glucose level measurements and the first four months of the amaranth intake regularly (Chart 2). This biochemical indicator increases throughout the study, attributed to the character of amaranth as a cereal, remembering that the usual diet of the patients did not undergo any modification (Chart 3). This indicator behavior in the patients significantly decreased between blood cholesterol samples at the beginning of the study and the first monitoring four months later, with total cholesterol increasing in the following two evaluation periods. However, to better understand this indicator was closely monitored with a lipid profile to characterize the cholesterol type (Chart 4). Throughout characterization of the cholesterol type found in the patients, the study showed a significant increase in HDL between six months and one year after the dietary intervention (Chart 5). Between six months and 12 months after the intervention with amaranth, the research registered an increase in LDL cholesterol levels. Although there was no significant weight loss, this component of body composition 
remained stable throughout the entire study group. Therefore the Body Mass Index prevailed stable (Table 1). About this indicator, the women in the study had a slight decrease in their hip circumference (Table 2). According to the results, the patients' blood levels over a year evidenced a decrease in glucose between the initial and final states. Regarding triglycerides, these had an upward behavior in the patients. Concerning total cholesterol, this indicator presented fluctuations, and the initial and final evaluations were practically the same. The determinations of the lipid profile, the HDL of the patients rose significantly; LDL also showed an increase, although in a lesser proportion than HDL. About the levels of VLDL cholesterol, they remained without considerable change. Finally, the patients' body weight did not increase. To summarize, Table 3 depicts the different variables that were analyzed using the Friedman test. This table shows the initial and final behavior of the parameters that were significant throughout the study: glucose, triglyceride, and cholesterol levels, as well as the HDL, LDL, and VLDL levels of the patients. Meanwhile, Table 4 shows that both cholesterol and VLDL did not change their levels between the initial and final states (Tables 5 \& 6). On the other hand, the triglycerides, HDL, and LDL increased significantly compared to the decreased glucose level.

Table 1: Body mass index of the patients over a year.

\begin{tabular}{|c|c|c|c|c|}
\hline \multirow{2}{*}{ Statistic } & \multicolumn{3}{|c|}{ Evaluation } \\
\cline { 2 - 5 } & First & Second & Third & Fourth \\
\hline Number of individuals & 29 & 29 & 29 & 29.15 \\
\hline Mean & 29.51 & 29.49 & 29.40 & 28.40 \\
\hline Median & 29.00 & 29.00 & 3.64 & 3.81 \\
\hline Standard deviation & 3.92 & 4.00 & 20.70 & 20.90 \\
\hline Minimum & 20.00 & 20.90 & 38.30 & 37.60 \\
\hline Maximum & 38.80 & 38.40 & & \\
\hline
\end{tabular}

Table 2: Hip circumference $(\mathrm{cm})$ of patients over a year.

\begin{tabular}{|c|c|c|}
\hline \multirow{2}{*}{ Statistic } & \multicolumn{2}{|c|}{ Evaluation } \\
\cline { 2 - 4 } & Initial & 29 \\
\hline Number of individuals & 29 & 105.2 \\
\hline Mean & 106.1 & 104.0 \\
\hline Median & 106.5 & 8.7 \\
\hline Standard deviation & 8.5 & 93.0 \\
\hline Minimum & 94.0 & 121.5 \\
\hline Maximum & 119.0 & \multicolumn{2}{c|}{} \\
\hline
\end{tabular}

Table 3: One-way repeated measures analysis of variance by ranks. Friedman test of biochemical and anthropometric indicators (n $=29$ ).

\begin{tabular}{|c|c|c|c|c|c|c|c|}
\hline \multirow{2}{*}{ Variable } & \multicolumn{4}{|c|}{ Evaluation* } & \multirow{2}{*}{$\chi^{2}$} & \multirow{2}{*}{$\mathbf{g l}^{* *}$} & \multirow{2}{*}{$\mathbf{p}$} \\
\hline & First & Second & Third & Fourth & & & \\
\hline Glucose & 3.10 & 2.34 & 2.38 & 2.17 & 8.88 & 3 & 0.03 \\
\hline Triglycerides & 1.76 & 2.00 & 3.03 & 3.21 & 27.58 & 3 & $<0.01$ \\
\hline Cholesterol & 3.00 & 1.24 & 2.45 & 3.31 & 43.39 & 3 & $<0.01$ \\
\hline Weight & 2.69 & 2.66 & 2.62 & 2.03 & 5.37 & 3 & 0.15 \\
\hline BMI & 2.78 & 2.72 & 2.45 & 2.05 & 6.08 & 3 & 0.11 \\
\hline
\end{tabular}

Note:

*Mean rank values

**Degrees of freedom 
Table 4: Evaluation of differences between the initial state and the final state of the biochemical and anthropometric indicators. Wilcoxon matched-pairs signed rank test.

\begin{tabular}{|c|c|c|c|c|c|c|c|c|}
\hline \multirow{2}{*}{ Variable } & \multicolumn{3}{|c|}{ Evaluation } & \multirow{2}{*}{$\begin{array}{c}\text { Number of } \\
\text { negative } \\
\text { ranks }^{1}\end{array}$} & \multirow{2}{*}{$\begin{array}{c}\text { Number } \\
\text { of positive } \\
\text { ranks }\end{array}$} & \multirow{2}{*}{ Ties } & \multirow{2}{*}{$\mathbf{z}$} & \multirow{2}{*}{$\mathbf{p}$} \\
\hline & $\mathbf{N}$ & Initial & Final & & & & & \\
\hline Glucose & 29 & 131.20 & 113.96 & $22(14.91)^{*}$ & 7 (15.29) & 0 & $\neg-2.39$ & 0.02 \\
\hline Triglycerides & 29 & 128.37 & 184.66 & $5(6.4)$ & 24 (16.79) & 0 & -4.01 & $<0.001$ \\
\hline Cholesterol & 29 & 211.91 & 224.19 & $11(13.00)$ & $18(16.22)$ & 0 & -1.61 & 0.11 \\
\hline HDL & 29 & 44.98 & 54.84 & $4(4.25)$ & $25(16.72)$ & 0 & -4.34 & $<0.001$ \\
\hline LDL & 29 & 118.77 & 138.69 & $3(15.67)$ & $26(14.92)$ & 0 & -3.69 & $<0.001$ \\
\hline VLDL & 29 & 34.70 & 37.67 & $12(14.42)$ & $17(15.41)$ & 0 & -0.96 & 0.34 \\
\hline
\end{tabular}

Note:

${ }^{1}$ The level of the final evaluation is lower than that of the initial assessment.

${ }^{2}$ The level of the final evaluation is higher than that of the initial assessment.

*The number in parentheses refers to Mean rank values.

Table 5: Weight $(\mathrm{kg})$ of the patients over a year.

\begin{tabular}{|c|c|c|c|}
\hline \multirow{2}{*}{ Statistic } & \multicolumn{2}{|c|}{ Evaluation } \\
\cline { 2 - 4 } & First & Second & Third \\
\hline Number of individuals & 29 & 29 & 29 \\
\hline Mean & 70.98 & 70.79 & 69.96 \\
\hline Median & 70.00 & 69.90 & 68.80 \\
\hline Standard deviation & 10.22 & 10.64 & 9.72 \\
\hline Minimum & 54.00 & 53.29 & 5.10 \\
\hline Maximum & 97.00 & 95.40 & 54.00 \\
\hline
\end{tabular}

Table 6: Waist circumference $(\mathrm{cm})$ of the patients over a year.

\begin{tabular}{|c|c|c|}
\hline \multirow{2}{*}{ Statistic } & \multicolumn{2}{|c|}{ Evaluation } \\
\hline & Initial & Final \\
\hline Number of individuals & 29 & 29 \\
\hline Mean & 94.0 & 92.9 \\
\hline Median & 92.0 & 90.0 \\
\hline Standard deviation & 9.5 & 10.9 \\
\hline Minimum & 74.0 & 72.0 \\
\hline Maximum & 115.0 & 123.0 \\
\hline
\end{tabular}




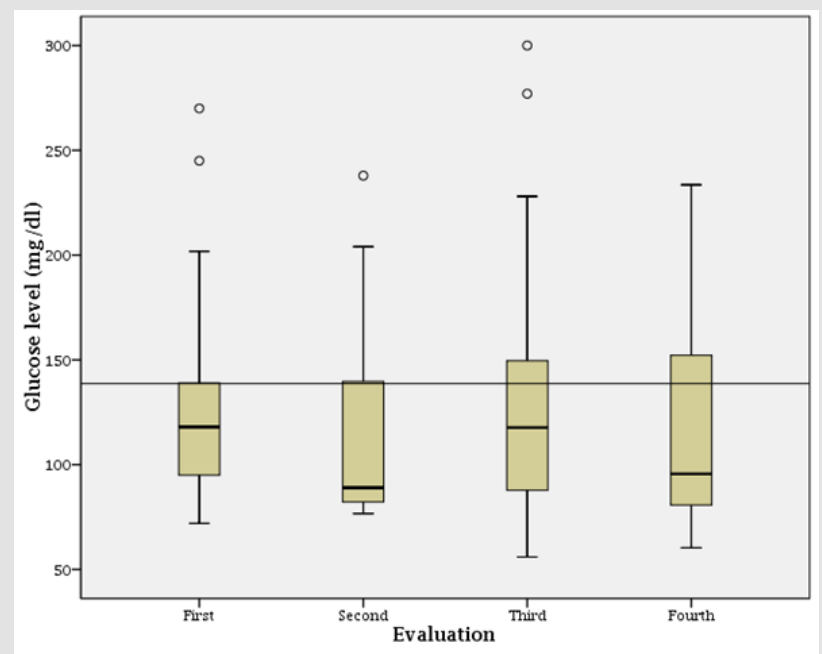

Chart 1: Glucose levels behavior.

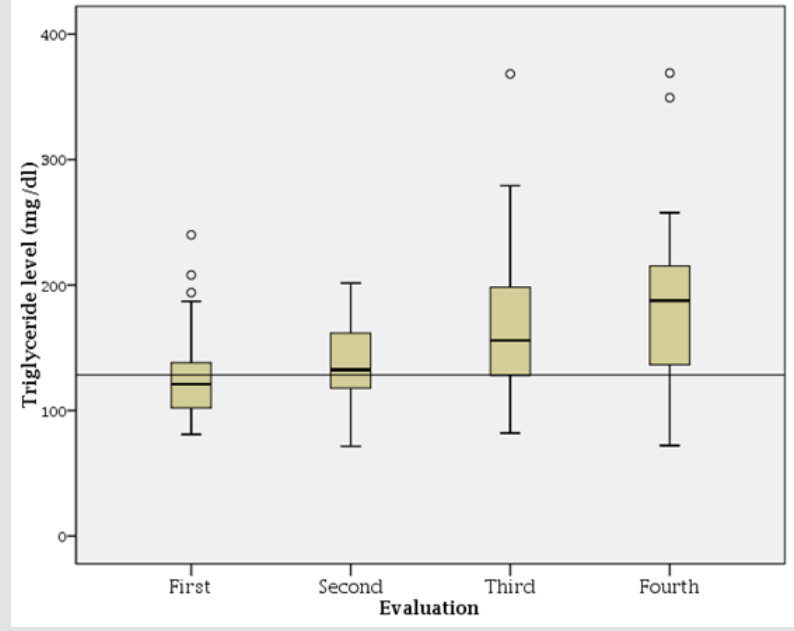

Chart 2: Triglyceride levels.

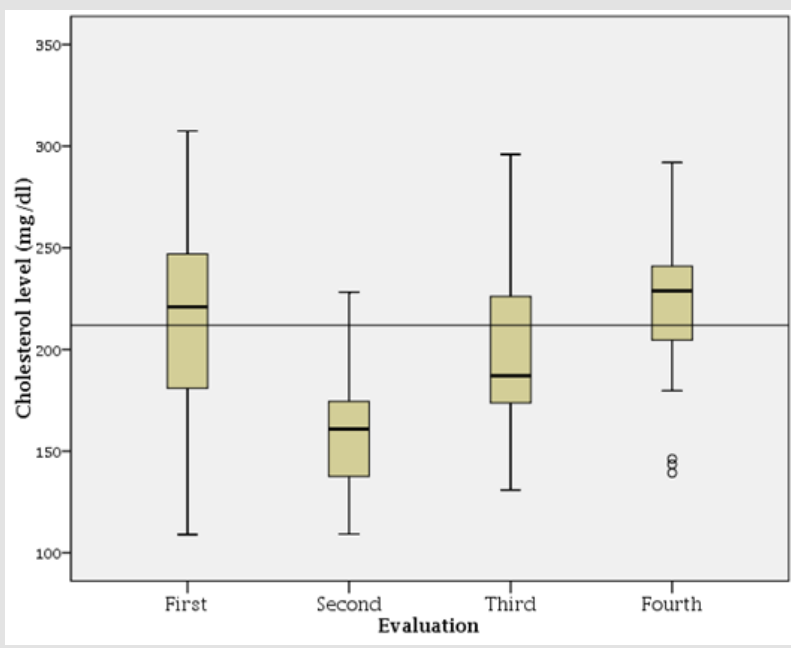

Chart 3: Cholesterol levels. 


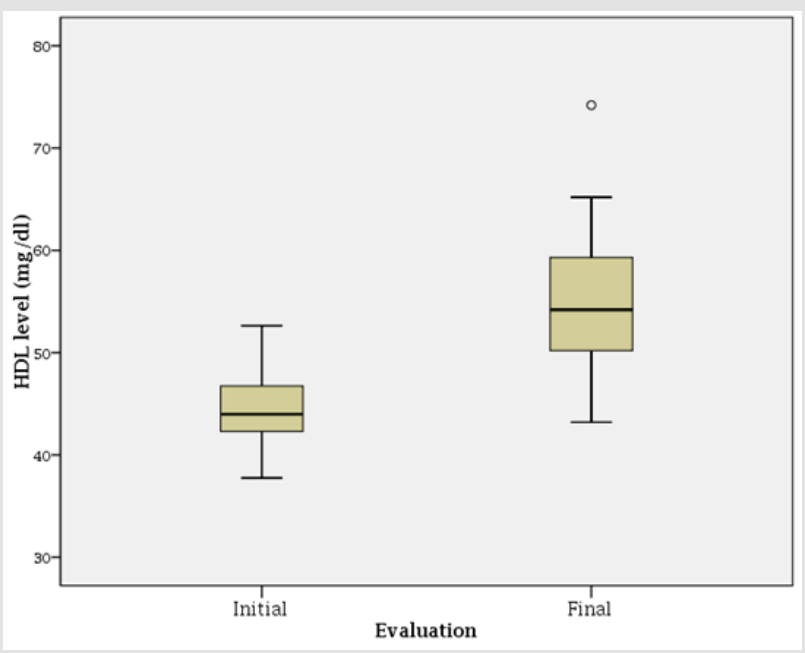

Chart 4: High-density lipoprotein levels (HDL).

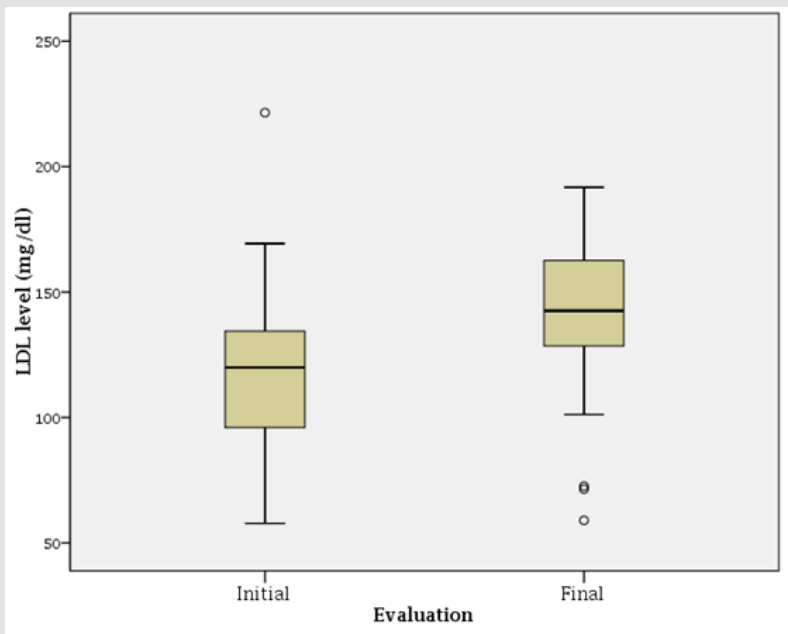

Chart 5: Low-density lipoprotein levels (LDL).

\section{Conclusion}

The study evidenced that the habitual consumption of amaranth has a positive effect determined from the amaranth active protein fraction with its inhibitory capacity of DPP-IV related to insulin secretion and the soluble fiber present in amaranth for glycemic control. The presence of polyunsaturated fats allowed an increase in HDL levels. Although the study identified that the amaranth's behavior could be considered a functional food of habitual consumption for the DM2 patients, further studies among a more significant number of individuals will allow emitting that this cereal contributes to improving their quality of life.

\section{Acknowledgement}

This project was funded by por Fundación Mujer Banorte (2015-2016) and México Tierra de Amaranto AC.

\section{References}

1. Goday A (2002) Epidemiología de la diabetes y sus complicaciones no coronarias. Revista Española de Cardiología 55(6): 657-670.

2. Navarrete C, Cartes Velásquez R (2012) Prevalencia de diabetes tipo 2 y obesidad en comunidades Pehuenches, Alto Biobio. Revista Chilena de Nutrición 39(3): 17-25.

3. Sarabia AB, Can VA y Guerrero CJ (2015) Identificación de Factores de Riesgo de la Diabetes Mellitus Tipo 2 en Adultos de 30 a 60 Años de edad en la Comunidad de Isla Aguada, Municipio de Ciudad del Carmen, Campeche. Revista Iberoamericana para la Investigación y el Desarrollo Educativo 5(10): 18-33.

4. (2017) Organización Panamericana de la Salud/Organización Mundial de la Salud. Diabetes.

5. (2015) Organización Mundial de la Salud. Diabetes: Datos y cifras. Nota descriptiva 312. 2012. Ginebra, Suiza.

6. Gómez Encino GC, Cruz León A, Zapata Vázquez RY, Morales Ramón F (2015) Nivel de conocimiento que tienen los pacientes con Diabetes Mellitus tipo 2 en relación a su enfermedad. Salud en Tabasco 21(1): 1725. 
7. Urban Reyes B, Coghlan López J y Castañeda SO (2015) Estilo de vida y control glucémico en pacientes con Diabetes Mellitus en el primer nivel de atención. Atención Familiar 22(3): 68-71.

8. Portero KC, McLellan SM, Barbalho M, Cattalini AC Lerariol A (2007) Diabetes Mellitus do tipo 2, síndrome metabólica e modificação no estilo de vida. Revista de Nutrición Campinas 20(5): 515-524.

9. (2018) Federación Internacional de Diabetes. Atlas de la Diabetes de la FDI. Bruselas, Bélgica: FID.

10. Miranda P y Guazo D (2017) INEGI: Diabetes, el más mortífero de México. El Universal.

11. Gutiérrez JP, Rivera Dommarco J, Shamah Levy T, Villalpando Hernández S, Franco A, et al. (2012) Encuesta Nacional de Salud y Nutrición 2012 Resultados Nacionales. Cuernavaca, México: Instituto Nacional de Salud Pública 55(3): 332-340.

12. Hernández Ávila M, Rivera DJ, Shamah Levy T, Cuevas NL, Gómez AL, et al., (2016). Encuesta Nacional de Salud y Nutrición de Medio Camino. Ensanut MC, pp. 1-149.

13. Mauricio Hernández Ávila, Juan Pablo Gutiérrez, Nancy Reynoso Noverón (2013) Diabetes en Michoacán. El Sol de Morelia 55(2): 129-136.

14. Martínez L (2016) Seguridad alimentaria, autosuficiencia y disponibilidad del amaranto en México. Problemas del Desarrollo 186(47): 1-26.

15. Bressani R (1989) The proteins of grain amaranth. Food Reviews International 5(1): 13-38.

16. Marcone F, Kakuda Y, Rickey Y (2004) Amaranth as a rich dietary source of beta-sitosterol and other phytosterols. Plants for human nutrition 58(1): 207-211.

ISSN: 2574-1241

DOI: 10.26717/BJSTR.2021.39.006330

María Antonieta Ochoa Ocaña. Biomed J Sci \& Tech Res

(C) (P) This work is licensed under Creative

Submission Link: https://biomedres.us/submit-manuscript.php
17. Morales GJC, Vázquez N y Bressani R (2009) El amaranto: Características físicas, químicas, toxicológicas y funcionales y aporte nutrici. Instituto Nacional de Ciencias Médicas y Nutrición Salvador Zubirán.

18. Montoya Rodríguez A, Gómez Favela MA, Reyes Moreno C, Milán Carrillo J, González de Mejía E (2015) Identification of Bioactive Peptide Sequences from Amaranth (Amaranthus hypochondriacus) Seed Proteins and Their Potential Role in the Prevention of Chronic Diseases. Comprehensive Reviews in Food Science and Food Safety 14(2): 139-158.

19. Sangameswaran B, Jayakar B (2008) Antidiabetic, antihyperlipidemic and spermatogenic effects of Amaranthus spinosus Linn on streptozotocininduced diabetic rats. Journal of Natural Medicines 62(1): 79-82.

20. Czerwinska E, Bartnikowskab H, Leontowicza E, Katrichc S, Trakhtenbergd, et al. (2004) Oat (Avena sativa) and amaranth (Amaranthus Hypochondriacus) meals positively affect plasma lipid profile in rats fed cholseterol containing diets. The Journal of Nutricional Biochemistry 15(10): 622-629.

21. Berger A, Monnard I, Dionisi F, Gumy D, Lambelet P, et al. (2003) Preparation of amaranth flakes, crude oils, and refined oils for evaluation ofcholesterol lowering properties in hamster. Food Chemistry 81(1): 119-124.

22. Espitia RE, Escobedo LD, Aguilar DM, Barrales LA (2015) El amaranto una opción al cambio climático y la soberanía alimentaria. En: Santiago TC, Ayala GA y Almaguer VG (Eds.)., Desarrollo y tecnologías. Aportes a los problemas de la sociedad. México: Plaza y Valdez, pp. 193-240.

23. Ochoa Ocaña MA, González MO (2014) Saberes y sabores de la Ciénega de Chapala. En prensa.

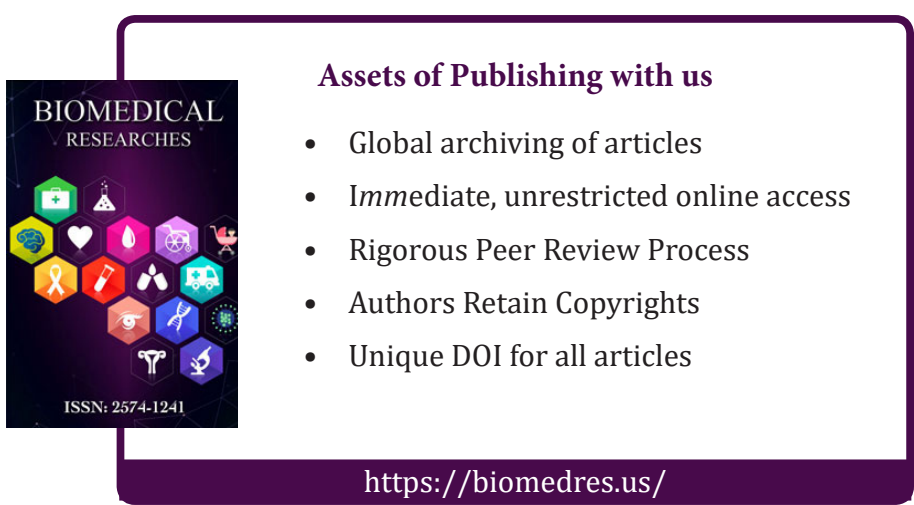

